Relations industrielles

Industrial Relations

\title{
A Note on the Effects on Unemployment Insurance, Minimum Wage Legislation and Trade Union Growth on Reported Unemployment Rates in Canada, 1950-1975
}

\author{
Herbert G. Grubel et Dennis R. Maki
}

Volume 36, numéro 4, 1981

URI : https://id.erudit.org/iderudit/029210ar

DOI : https://doi.org/10.7202/029210ar

Aller au sommaire du numéro

Éditeur(s)

Département des relations industrielles de l'Université Laval

ISSN

0034-379X (imprimé)

1703-8138 (numérique)

Découvrir la revue

Citer cet article

Grubel, H. G. \& Maki, D. R. (1981). A Note on the Effects on Unemployment Insurance, Minimum Wage Legislation and Trade Union Growth on Reported Unemployment Rates in Canada, 1950-1975. Relations industrielles / Industrial Relations, 36(4), 922-927. https://doi.org/10.7202/029210ar
Résumé de l'article

The paper analyzes the effects of the factors noted in the title on reported unemployment rates, both theoretically and empirically. The implications of the results for the natural rate debate and macroeconomic stabilization policies are briefly discussed.
Tous droits réservés (C) Département des relations industrielles de l'Université Laval, 1981
Ce document est protégé par la loi sur le droit d'auteur. L'utilisation des services d'Érudit (y compris la reproduction) est assujettie à sa politique d'utilisation que vous pouvez consulter en ligne. 


\title{
COMMENTAIRES
}

\section{A Note on the Effects of Unemployment Insurance, Minimum Wage Legislation and Trade Union Growth on Reported Unemployment Rates in Canada, 1950-75}

\author{
Herbert G. Grubel \\ and Dennis R. Maki
}

The paper analyzes the effects of the factors noted in the title on reported unemployment rates, both theoretically and empirically. The implications of the results for the natural rate debate and macroeconomic stabilization policies are briefly discussed.

In a previous paper ${ }^{1}$, one of the authors presented theoretical arguments outlining why minimum wage legislation, unemployment insurance schemes and the activities of trade unions might affect the reported rate of unemployment. The empirical work in that paper used pooled cross sectiontime series data to estimate a reduced-form model, ignored the potential influence of trade unions, and concentrated on the effects of minimum wage legislation on differences in unemployment rates between provinces. This note uses annual time series data covering the period 1950-75 to estimate separate supply and demand equations, and from these estimates calculates the effects of minimum wages, unemployment insurance and trade union growth on reported unemployment rates for Canada as a whole ${ }^{2}$.

Specification of the Model

The empirical model used is an augmented variant of the model used by Mincer ${ }^{3}$ to investigate the effects of minimum wages on unemployment. It

* GRUBEL, Herbert G., Professor, Department of Economics and Commerce, Simon Fraser University, B.C.

MAKI, Dennis R., Professor, Department of Economics and Commerce, Simon Fraser University, B.C.

** Research support under Canada Council Grant S75-1194 is acknowledged.

1 MAKI, Dennis R., "The Effect of Changes in Minimum Wage Rates on provincial Unemployment Rates, 1970-77”, Relations Industrielles, Vol. 34, 1979, pp. 418-30.

2 The time period chosen was dictated on both ends by the availability of reasonably consistent data, as 1975 is the last year for which Labour Force Survey data are available by the "old" definitions, and Statistics Canada has revised data to conform with the "new" definitions back only to 1966 .

3 MINCER, Jacob, “Unemployment Effects of Minimum Wages", Journal of Political Economy, Vol. 84, August 1976, pp. S87-104. 


\section{TABLE 1}

Regression Results, Annual Data, Canada, 1950-1975

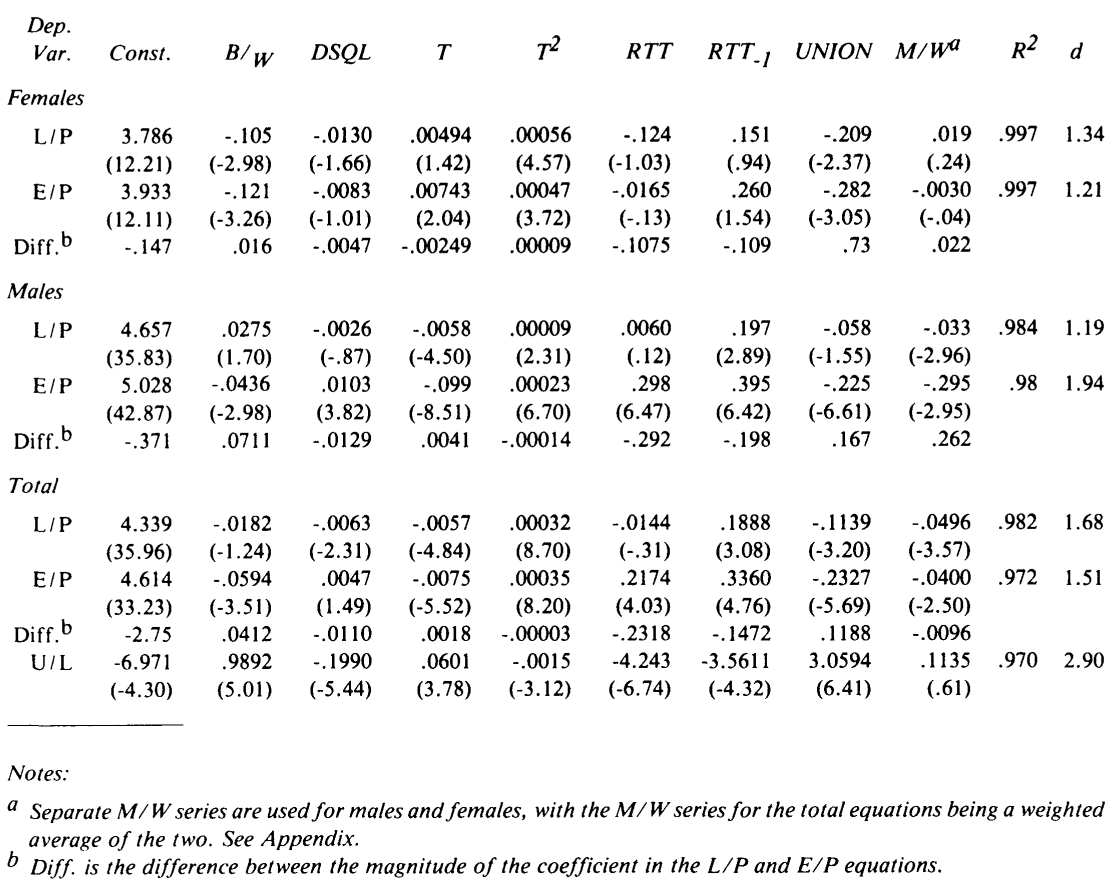

\section{General Results}

The coefficients of multiple determination are uniformly high for all equations, as expected for time series data. The Durbin-Watson coefficients cover a wide range, with those for the main equations $(\mathrm{L} / \mathrm{P}$ and $\mathrm{E} / \mathrm{P}$ for the total population) probably toward the high end of the indeterminate range 9 . We reestimated these equations using Generalized Least Squares with rho estimated by the Hildreth-Lu technique, and found no qualitative difference between these results and those reported in Table $1^{10}$. Since the Labour Force Survey data for 1950-52 are probably not of the same quality as those for subsequent years, and since the substantial changes to the unemployment insurance system in 1971 may not have been adequately modelled, we tested for stability on the main equations of interest, using Chow tests. The results indicated no evidence of a structural break between 1952 and $1953^{11}$,

9 The Durbin-Watson statistic is not tabled for as many regressors as are contained in our equations.

10 The Durbin-Watson statistic for L/P increased to 1.74 with a rho of 0.54 , and for $E / P$ it increased to 1.80 with a rho of 0.37 . These results are available from the authors upon request.

11 The $\mathrm{F}$ values were 1.76 for $\mathrm{L} / \mathrm{P}$ and 1.59 for $\mathrm{E} / \mathrm{P}$, with $(3,14)$ degrees of freedom. 
also bears a strong resemblance to the main equation of the model we previously used to investigate the unemployment effects of unemployment insurance ${ }^{4}$. The dependent variables are the labour force to population ratio $(\mathrm{L} / \mathrm{P})$ and the employment to population ratio $(\mathrm{E} / \mathrm{P})$, with an additional equation using the unemployment rate (U/L) also estimated as a crosscheck. Since one of the important theoretical arguments about the effects of government policies and labour market institutions is that these influences tend to interact, all equations were specified in multiplicative form, so that by taking logarithms we obtain the following basic form of equation for estimating purposes:

$$
\begin{aligned}
\ln \text { DEP }= & a_{0}+a_{1} \ln \mathrm{B} / \mathrm{W}+\mathrm{a}_{2} \ln \mathrm{DSQL}+\mathrm{a}_{3} \mathrm{~T}+\mathrm{a}_{4} \mathrm{~T}^{2}+ \\
& \mathrm{a}_{5} \ln \mathrm{RTT}+\mathrm{a}_{6} \ln _{\mathrm{RTT}_{-1}+\mathrm{a}_{7} \ln \mathrm{UNION}+\mathrm{a}_{8} \ln \mathrm{M} / \mathrm{W}} \\
& +\mathrm{e}
\end{aligned}
$$

where DEP is the dependent variable ( $\mathrm{L} / \mathrm{P} . \mathrm{E} / \mathrm{P}$ or $\mathrm{U} / \mathrm{P}), \mathrm{B} / \mathrm{W}$ is the ratio of unemployment insurance to wages, DSQL is the rate at which applicants for the receipt of these benefits are disqualified, T is a time trend, RTT is the ratio to its own trend of constant dollar gross national expenditure, UNION is the level of unionization and $\mathrm{M} / \mathrm{W}$ is the ratio of minimum to average wages ${ }^{5}$. The a's are coefficients to be estimated, and e is the error term. Ordinary least squares were used for all estimations.

The expectation was that $\mathrm{a}_{1}$ would be positive in the $\mathrm{L} / \mathrm{P}$ equation, negative in the $\mathrm{E} / \mathrm{P}$ equation, and hence positive in the $\mathrm{U} / \mathrm{L}$ equation, with the opposite pattern of signs expected for $\mathrm{a}_{2}$. The reasons for these theoretical expectations are contained in our earlier paper ${ }^{6}$. The coefficients of the RTT terms were expected to be positive in the $\mathrm{E} / \mathrm{P}$ equation and negative in the $U / L$ equation. The sign of these coefficients in the $L / P$ equation depends upon whether the discouraged worker or additional worker effect dominates, an issue which is not clear in the Canadian context, so no sign expectation was assigned. The coefficient of the minimum wage term was expected to be negative in the E/P equation. Mincer ${ }^{7}$ has shown that the effect of $M / W$ on $L / P$ (and hence $U / L$ ) is theoretically indeterminate. Since we are using the unionization measure suggested by Kahn and Moriume ${ }^{8}$, the sign expectations for $a_{7}$ are the same as for a 8 , for the same reasons. No sign expectations were assigned for the coefficients of the time trend terms.

We also estimated the equations separately for males and females, though the independent variables are in general not measurable sex-specific. Estimation results are shown in Table 1 .

4 GRUBEL, H.G., D. MAKI and S. SAX, "Real and Insurance-Induced Unemployment in Canada", Canadian Journal of Economics, Vol. 8, May 1975, pp. 174-91.

5 More detailed variable definitions and data sources are given in the appendix.

6 GRUBEL, H.G., et al., op. cit.

7 MINCER, J., op. cit.

8 KAHN, L. and K. MORIUME, “Unions and Employment Stability: A Sequential Logit Approach”, International Economic Review, Vol. 20, February 1979, pp. 217-35. 
but there was evidence of a break between 1971 and $1972^{12}$. Whether these results are due to inadequate modelling of the unemployment insurance program changes or to something else which was unique to the 1972-75 period cannot be determined.

Sign expectations were realized in all the "Male" equations, and except for $a_{1}$ in the $L / P$ equation of the "Total" estimates, but several unexpected signs occurred in the "Female" equations $\left(a_{1}\right.$ in both the L/P and E/P equations, $\mathrm{a}_{2}$ and $\mathrm{a}_{5}$ in the $\mathrm{E} / \mathrm{P}$ equation). Possibly this is due to the fact that the independent variables (except $\mathrm{M} / \mathrm{W}$ ) were not measured specifically for females due to lack of suitable data.

\section{Results for the Variables of Primary Interest}

Confining attention to the "Difference" rows in Table 1, the results indicate that increase in unemployment insurance benefit levels or decreases in the disqualification rates for these benefits both increase unemployment. Similarly, increases in the level of unionization increase unemployment, with a substantially larger effect for males than females. The results for males and females separately indicate increases in minimum wages increase unemployment, again substantially more so for males than females; but paradoxically the sign of the difference for the total equation is negative, indicating that although increased minimum wage levels reduce employment, they reduce labour force even more. The cross-check equation using $\mathrm{U} / \mathrm{L}$ as the dependent variable discloses a positive, but statistically non-significant, coefficient for the minimum wage term. Fortin and Phaneuf ${ }^{13}$ also found statistically insignificant results for their minimum wage variable, a result they attribute to multicollinearity.

There are many ways to give some meaning to the magnitudes of the estimated coefficients. We will do so by asking the following counterfactual question: what would have been the average rate of unemployment in Canada during the period $1972-75$ in relation to the one actually observed, if the key policy variables had been at the mean values observed in some base period, everything else remaining the same. We arbitrarily chose two base periods, 1952-55 and 1962-65. Using the earlier base period, the results indicate the unemployment rate would have been 1.1 percentage points lower, with changes in unemployment insurance accounting for 0.9 percentage points of this, unionization changes 0.8 percentage points, and minimum wages changes -0.6 percentage points ${ }^{14}$. Using the $1962-65$ base period, the total difference would have been 2.2 percentage points, with unemployment insurance accounting for 0.3 percentage points, unionization 2.2 percentage points ${ }^{15}$, and minimum wages -0.2 percentage points.

12 The $\mathrm{F}$ values were 4.20 for $\mathrm{L} / \mathrm{P}$ and 4.64 for $\mathrm{E} / \mathrm{P}$, with $(4,13)$ degrees of freedom.

13 FORTIN, P. and L. PHANEUF, "Why is the Unemployment Rate so High in Canada?", Paper presented at the Meetings of the Eastern Economic Association, Boston, May 10, 1979.

14 The counterfactual L/P and E/P were estimated using the "Total" equations in Table 1 , and then an implied $U / L$ computed using a population of $16,363.25$, the average over the 1972-75 period. Details of the calculation are available from the authors upon request.

15 The large difference between base periods in the effect ascribed to unionization is due to the fact that UNION was substantially lower in 1962-65 than in 1952-55. 
Finally, if whatever secular changes are captured in the time trends were also held constant at base period levels (in addition to the unemployment insurance, unionization and minimum wage variables), both base periods yield similar results: the unemployment rate in 1972-75 would have been 2.6-2.7 percentage points lower than actually observed. If one based the same counterfactual computation on the cross-check equation using $\mathrm{U} / \mathrm{L}$ as the dependent variable, the same overall estimate would obtain, but the $\mathrm{U} / \mathrm{L}$ equation would attribute much more of the difference to isolated factors, and less to the time trend.

Conclusion

The main point arising from these estimations, which we have not noted elsewhere in the literature, is the possibility that trade union activity may have a substantial effect on the level of reported unemployment. The question deserves additional investigation.

\section{BIBLIOGRAPHY}

CLOUTIER, J., "The Distribution of Benefits and Costs of Social Security in Canada, 1971-75”, Economic Council of Canada Discussion Paper No. 108, 1978.

FORTIN, P. and L. PHANEUF, "Why is the Unemployment Rate so High in Canada?", Paper presented at the Meetings of the Eastern Economic Association, Boston, May 10, 1979. GRUBEL, H., D. MAKI and S. SAX, "Real and Insurance-Induced Unemployment in Canada”, Canadian Journal of Economics, Vol. 8, May 1975, pp. 174-191.

KAHN, L. and K. MORIUME, "Unions and Employment Stability: A Sequential Logit Approach”, International Economic Review, Vol. 20, February 1979, pp. 217-35.

KRUGER, A., "The Direction of Unionism in Canada", in R. MILLER and F. ISBESTER (eds.), Canadian Labour in Transition, Scarborough, Ont., Prentice-Hall of Canada, 1971, pp. 85-118.

MAKI, D., "The Effect of Changes in Minimum Wage Rates on Provincial Unemployment Rates, 1970-77”, Relations Industrielles, Vol. 34, pp. 418-30.

MINCER, J., “Unemployment Effects of Minimum Wage”, Journal of Political Economy, Vol. 84, August 1976, pp. S87-104.

SWIDINSKY, R., "Minimum Wages and Teenage Unemployment in Canada", Canadian Journal of Economics, Vol. 13, February 1980, pp. 158-70.

STATISTICS CANADA, Canadian Statistical Review (11-003), Various issues.

STATISTICS CANADA, Canadian Statistical Review, Historical Summary 1970 (11-505), 1972.

STATISTICS CANADA, Historical Labour Force Statistics (71-201), 1973.

STATISTICS CANADA, Statistical Report on the Operation of the Unemployment Insurance Act (73-001), Various issues.

\section{APPENDIX}

\section{Variable Names and Data Sources}

$L / P$ - Labour force participation rate, using the "old" Labour Force Survey definition, expressed as a percentage. Data from Statistics Canada, 11-505, p. 48 for 
1950-71; more recent years from Statistics Canada, 11-003, various issues for the aggregate. Data disaggregated by sex for 1953-72 from Statistics Canada, 71-201, Feb. 1973; for more recent years from Statistics Canada, 11-003, various issues; and for 1950-52 from information obtained from Statistics Canada, Vancouver office, by telephone. Simple averages of quarterly data (five observations for 1952) were used to obtain 1950-52 values.

$E / P \quad-$ Employment to population ratio, expressed as a percentage. Same sources as for L/P.

$U / L$ - Unemployment to labour force ratio, expressed as a percentage. Data from Statistics Canada, 11-505, p. 48 for 1950-71; more recent data from Statistics Canada, 11-003, various issues.

$B / W \quad-$ The ratio of average weekly unemployment insurance benefits to industrial composite average weekly wages and salaries. Benefits computed from total benefit payments and total weeks compensated, data for 1950-1971 from Statistics Canada, 11-505, p. 50; for more recent years from Statistics Canada, 11-003, various issues. Wage data for 1950-1970 from Statistics Canada, 11-505, p. 56; more recent years from Statistics Canada, 11-003, various issues. The average weekly wages and salaries series for 1950-56 was multiplied times 1.0004 to convert to 1960 SIC, the constant being estimated from the 1957-60 overlap period. The benefit-wage ratios for 1972 and 1973 were multiplied times 0.827 , for 1974 by 0.820 , and for 1975 by 0.835 to adjust for the fact that benefits became subject to income tax in 1972. These correction factors are based on information in J.E. Cloutier, "The Distribution of Benefits and Costs of Social Security in Canada 1972-75”, Economic Council of Canada, Discussion Paper No. 108, p. 40.

$D S Q L$ - Disqualifications and disentitlements for unemployment insurance benefits, from Statistics Canada, 73-001, various issues, per 10,000 weeks compensated. Sources for data on weeks compensated noted under $B / W$.

$T \quad-$ A series of consecutive integers, zero in $1945 . \mathrm{T}^{2}$ is simply $\mathrm{T}$, squared.

RTT - The ratio to exponential trend of constant dollar Gross National Expenditure (GNE). Data on GNE from Statistics Canada, 11-505, p. 16 with change of base to 1971 for 1946-1960; Statistics Canada, 11-003 December, 1977, for 1961-76. The natural logarithm of GNE was regressed on a intercept and a series of consecutive integers using annual data for the period 1946-76. The difference between the actual and prediction values is $1 \mathrm{n} \mathrm{RTT}$, and ln RTT $_{-1}$ is the same variable lagged are period.

UNION - The ratio of union membership to non-agricultural paid employment, expressed as a percentage. Data on union membership for 1950-68 from Arthur M. Kruger, "The Direction of Unionism in Canada", in R. Miller and F. Isbester (eds.), Canadian Labour in Transition, Scarborough, Ont., Prentice-Hall of Canada, 1971, p. 94; and for subsequent years from Labour Gazette, March 1970, August 1971, July 1973, July 1974, August 1975, May 1976 and May 1977. Data for denominator from Statistics Canada, 11-505, p. 48 for 1950-71; more recent years from Statistics Canada, 11-003, various issues.

$M / W \quad$ - The ratio of coverage weighted minimum wages applicable to adult workers to average hourly earnings in manufacturing. Data for males and females separately are given in R. Swidinsky, "Minimum Wages and Teenage Unemployment in Canada", paper presented at Canadian Industrial Relations Association Meetings, London, Ontario, May 1978, p. 8. We took weighted averages of the male and female series, using relative labour force numbers as weights, to construct the $\mathrm{M} / \mathrm{W}$ series used in the "total" equations in Table 1 . 